\author{
Яна КИРИЛЕНКО, \\ orcid.org/0000-0001-9823-3897 \\ кандидат мистеитвознавства, \\ дочент кафедри академічного та естрадного вокалу \\ Інституту мистеитв \\ Киїського університету імені Бориса Грінченка \\ (Київ, Україна)y.kyrylenko@kubg.edu.ua
}

\title{
«ДУХОВНИЙ КОНЦЕРТ» М. СКОРИКА: \\ ЖАНРОВО-СТИЛЬОВЕ РЕПРЕЗЕНТУВАННЯ НЕОРЕЛІГІЙНОЇ МОДЕЛІ УКРАЇНСЬКОГО ХОРОВОГО КОНЦЕРТУ
}

\begin{abstract}
Жанрово-стильова модель духовного кониерту достатньою мірою багатоскладова, щчо визначає можливості їі осібного дослідження. Для узагальненої характеристики спрямування в українському духовно-хоровому кониерті на зламі XX - XXI століть використовується поняття «неорелігійний», шьо передбачає збереження канонів службового співу та нове бачення можливостей жанру вже за межами храмової практики. У статті за основу взято певний жанрово-стильової підвид неорелігійного украйнського хорового концерту (на прикладі «Духовного концерту» М. Скорика), новітні риси якого схарактеризовані з погляду їхнього прояву на рівні національних мовних ознак. Використані методи розвідки трунтуються на наукових компаративних, структурно-функціональних й аналітичних критеріях, інтонаційно-мовних підходах, принцииах системного, інтерпретаційного, семантичного, стилістичного, хорознавчого аналізу. Створений у руслі нової сакральності, твір М. Скорика поєднує напрями, щзо базуються на прототипах духовно-хорових творів тогочасності та на їх відтворенні в дусі української релігійної ментальності. В одночастинній поемно-хоровій композицї барвисто перегукуються мотиви подяки та покаяння на тлі розгортання драматичних подій. Об'єктивна молитовність, насичуючись послідовно накопичувальною експресією, відіграє роль як рефрену, так і структурної арки, щзо свідчить про естетичну присутність автора у творі. Твір має такі своєрідні риси, як симфонічна картинність, де хор і голоси солістів подібні до оркестрової; жанр другого плану - кониерт-поема; сценічна перформативність, щзо поєднана з національно-мовними підвалинами завдяки прозорій образності. Хорове концертне мислення композитора набуває значення в системі ансамблевого інтонування та виокремлює образно-емоційний зміст твору.
\end{abstract}

Ключові слова: неорелігійна модель хорового кониерту, діалогічність, антифонність, образна драматургія, сиенічна репрезентативність.

\author{
Yana KYRYLENKO, \\ orcid.org/0000-0001-9823-3897 \\ Candidate of Art History, \\ Associate Professor at the Academic and Pop Vocal Department \\ Institute of Arts \\ of Borys Grinchenko Kyiv University \\ (Kyiv, Ukraine) y.kyrylenko@kubg.edu.ua
}

\section{"SPIRITUAL CONCERT" BY M. SKORYK: GENRE-STYLIZED NEORELIGIOUS MODEL REPRESENTATION OF UKRAINIAN CHORAL CONCERT}

The genre-stylized model of sacred concert is sufficiently multi-syllable, that determines the possibility of its special research. The concept "neoreligious" is used for the general characteristic of direction in Ukrainian spiritual and choral concert at the turn of XX - XXI centuries, that means the canons save of service singing and the new vision of genre potentialities now beyond the bounds of temple practice. The definite genre-styled subdivision of neoreligious Ukrainian choral concert is taken as a principle in the article (as instance of "Spiritual concert" by M. Skoryk), the latest features of which are characterized in aspect of their developing on the level of national linguistic signs. The applied investigation methods are based on scientific comparative, structural and functional, analytical criteria, intonation-lingual approaches, principles of systemic, interpretive, semantic, stylistic, chorological analysis. Created in the line of new sacredness, M. Skoryk's composition combines the ways, based on prototypes of spiritual and choral works of that time and their reproduction in the spirit of Ukrainian religious mentality. In one-part of poem-choral composition the motives of gratitude and repentance colourfully resonate against dramatic events development. The objective prayerfulness, saturating with gradually accumulative expression, plays the role both as refrain and structural arch, that reveals the author's aesthetic presence in composition. The composition contains such peculiar features as symphonic pictoriality, where the choir 
and soloists'voices are similar to orchestral; the genre of secondary plan - the concert-poem; the scenic performativity connected with national-linguistic foundations due to intelligible imagery. The composer's choral concert mentality attains the value in system of ensemble intonation and distinguishes the figurative and emotional content of composition.

Key words: neoreligious model of choral concert, dialogicity, antiphonis, presentative dramaturgy, scenic representability.

Постановка проблеми. Актуальність статті зумовлена необхідністю створення нової моделі науково-творчої інтерпретації; розбіжністю між надзвичайною значущістю, новаторською природою феномену композитора та браком теоретичного узагальнення його хорової творчості; недостатньою систематизацією тенденцій, властивих сьогочасному українському духовному хоровому концерту, та значущістю перформативності в сьогоденних модифікаціях жанру.

Аналіз досліджень. Різнопланова стильова творчість, художній образ М. Скорика привертає постійну увагу музикознавців і критиків щодо ї наукового осмислення. У сучасному українському музикознавстві $\epsilon$ чимало робіт, що розглядають вітчизняне хорове мистецтво в його теоретичних і виконавських аспектах. У грунтовних монографіях Л. Кияновська «розшифровує» творчість митця, доповнює розповідь діалогами 3 композитором і аналізом його найновіших творів; М. Антоненко схарактеризована позалітургійна духовна музика у творчості сучасних українських композиторів кінця XX - початку XXI ст., а саме незалежність музичної мови від канонічних норм, самобутне авторське бачення сакрального змісту, що простежується в хоровому циклі М. Скорика «Три псалми»; Н. Бєлік-Золотарьовою зроблено висновки щодо використання хорового компонента в хоровій драматургії опери М. Скорика «Мойсей»; О. Комендою розкрито багатогранну творчу особистість М. Скорика, якого віднесено до типу універсала-композитора; І. Коноваловою викладено віддзеркалення постмодерного світогляду та визначено сутність, контексти, суб'єктивноособистісне у творчості М. Скорика; І. Куриляк відзначено новаторські принципи трактування М. Скориком ролі хору; О. Мануляком розглянуто в контексті основних тенденцій української релігійної музики «Духовний концерт» М. Скорика як барокову модель, поєднану з пізньоромантичним змістом; В. Степурком обгрунтовано філософсько-поетичний символізм «Літургії» М. Скорика як вияв мистецької інтроверсії; Д. Харитоновою проаналізовано символічне мислення М. Скорика на прикладі камерних інструментальних сонат.

Незважаючи на чималий корпус досліджень, що дотично розкривають межі унікальності композитора М. Скорика, в українській науці не знайдено системних праць, присвячених без- посередньо комплексному та багатоаспектному індивідуально-стильовому трактуванню жанру неорелігійної моделі.

Мета статті - простежити сукупність жанрових і стильових ознак неорелігійного хорового концерту на прикладі «Духовного концерту» М. Скорика.

Виклад основного матеріалу. 3 початку 90-х pp. ХХ ст. у вітчизняній хоровій музиці, як компенсація попередньої ідеологічної заборони, бурхливо розвиваються духовні жанри, що відбилося у творчому напрямі, який дістав назву «нової сакральності» («нової релігійної хвилі»). По суті, у цей період «формується можливість зіставлення двох головних історичних типів інтерпретації духовності в музиці», у яких, «по-перше, відбилися фундаментальні жанрові основи музичної творчості, по-друге, позначилися ті потреби в духовності, які сьогодні переживають своє Відродження і направляють жанрові пошуки сучасних українських композиторів у руслі нового синтезу» (Александрова, 2008: 4).

Життєва й художня обумовленість ренесансу духовно-хорових жанрів реалізується на основі двох тенденцій, що особливо яскраво проявляються в умовах інтонаційної кризи (Б. Асаф'єв), коли наявні музично-інтонаційні системи, зокрема і такі глобальні, як жанр і стиль, переінтонуються. Як зазначає Н. Александрова, «уже iз середини XIX ст. у хоровій вітчизняній музиці окреслюються дві рівнозначні жанрові тенденції. Перша 3 них пов'язана 3 розвитком традиційного службового (храмового) співу, зі збереженням i зростанням інтересу до культової хорової музики як до найбільш древньої і тривалої традиції національного мистецтва. Друга тенденція означає нові уявлення про можливості хорової музики - уже за межами культової практики та у зв'язку з усім досвідом світської композиторської творчості, означає нове ставлення до жанрово-семантичних можливостей хорової музики, починає вимагати окремої форми, автономних композиторських рішень» (Александрова, 2008: 5).

У практиці хорового музикування на зламі $\mathrm{XX}$ $\mathrm{XXI}$ ст. духовний концертно-хоровий жанр представлений двома напрямами, які у принципі можна визначити, як це робить О. Стець, як «позахрамове» $\mathrm{i}$ «богослужбове» (Стець, 2012: 19). В Україні тенденція до «відокремлення» цих напрямів 
менш істотна. Українські автори великою мірою орієнтуються не на жанровий канон православної літургії, де музика становить невід'ємну частину синкретичного організму богослужіння, хоча такі зразки теж $\epsilon$, а на художній модус, що походить від ідеї концерту у храмі, коли хоровий твір $\epsilon$ можливою «вставкою» у богослужбовий чин.

Тому для узагальненої характеристики тенденцій в українському духовно-хоровому концерті на зламі XX-XXI ст. уживається поняття «неорелігійний», що означає можливість виконання більшості таких творів як у кліросних умовах, так і $з$ концертних майданчиків. Основу моделі неорелігійного хорового концерту становить коло текстових джерел, які формують літературну основу жанру. Крім традиційних псалмів, тропарів, кондаків, сюди включаються й інші тексти - молитов, євхаристій, херувимських, проповідей тощо, у результаті чого складається досить розгалужена образно-семантична система неорелігійної моделі українських хорових концертів, що диференціюються «за їх приналежністю до одного 3 утілюваних духовних станів: молитовно-покаянного, хвалітного, євхаристичного (подячного)» (Стець, 2012: 19).

Сучасні українські духовні концерти з погляду жанрових форм і добірки сакральних текстів (як і в інструментальному концерті) поділяються на дві основні групи: одночастинні концерти - духовно-хорові поеми і багаточастинні (від трьох i більше частин) концерти-цикли, організовані за сюїтним принципом. Зразком одночастинної форми-моделі $€$ «Духовний концерт» для мішаного хору і солістів М. Скорика на тексти молитов 3 Свангелія, створений у 1998 р. (Скорик, 2005: 48-65).

Жанровим напрямом Концерту є молитва, представлена станами славлення, подяки та покаяння. Молитва відіграє роль як рефрену, так і структурної арки («Отче наш», Lento). У середніх розділах даної одночастинної поемно-хорової композиції розгортаються драматичні події, пов'язані з мотивами подяки й покаяння. Це Andante (від т. 70) («Хто живе під захистом Всевишнього <...») із середнім розділом Animato (від т. 81) і вміщеним у його рамках коротким фугато на текст «Нога твоя не спіткнеться об камінь <...> (від т. 90). Далі йде варіантний повтор темпового модусу Andante (від т. 112) з подальшою «хибною репризою» Lento (від т. 133) на текст «Святий Боже, Святий Кріпкий <..>», що повторює чотиритактну заставку-епіграф з початку Концерту, але не у вихідному ля-мінорі, а в ре-мінорі.

Наявність хибної репризи свідчить про елементи розробковості, початок прояву яких вона знаменує. Іде розвивальна частина форми, що грунтована на інтонаціях благання-прохання про порятунок «грішної душі» та блаженство праведників (т. 137) («Пом'яни, Господи, душі рабів Твоїх!»). 3 т. 193 повертається темп Andante («Помилуй мене, о Боже, по милості Твоїй $<\ldots>\gg)$. Після досягнення генеральної кульмінації (т. 283) («Плачу, плачу і ридаю <..>») йде справжня реприза на текст молитви «Отче наш», яка практично цілковито повторює початковий експозиційний варіант молитви (до т. 313), після чого дається кода-підсумок Larghetto («Вічная пам'ять») на квінтовому органному пункті тоніки «ля», у якої символічно, з огляду на «величальножалісну» молитовну концепцію Концерту, роздвоєна терція («до-дієз» і «до-бекар» водночас).

М. Скорик як визнаний майстер концертного жанру трактує жанрову форму хорового концерту не як структурну модель, а як персональний авторський принцип мислення-стилю. Концерт $\epsilon$ титульним жанром творчості композитора, що i визначає характер індивідуально-авторських моделей утілення концертного модусу згідно 3 виконавським складом і видовим (вокальний, інструментальний, сольний, колективний, змішаний) стилем концертності.

Отже, у даному хоровому Концерті мають бути відображені субстанція й атрибутика концертності щодо іiї видової специфіки - концерту для хору а cappella. 3 атрибутів концертності головним для стилістичного втілення в М. Скорика $є$ діалогічність. У «Духовному концерті» вона проявляється на всіх рівнях драматургії та форми, а також на вищому рівні концептуальності, на якому авторський стиль постає як тип «музичного звукоспоглядання» (вислів М. Римського-Корсакова).

Діалогеми представлені в «Духовному концерті» на двох масштабних рівнях, перший з яких визначається як стильовий, а другий - як стилістичний. Стильовий рівень означає акцент на змісті, образності, оперуванні жанрами та стильовими лексемами у створенні змістової форми твору як композиційно-драматургічної єдності та цілісності в концептуальному сенсі. Стилістичний рівень - переважно мовний, передбачає комплекс засобів мови та технічних прийомів, обраних композитором для реалізації концептуального задуму. Водночас «стиль» і «мова» прагнуть до єдності та взаємозумовлюють одне одного. Міра досягнутої між ними єдності становить основу художньої цінності твору як культурного артефакту.

Композитор орієнтується на усталену модель духовно-концертного жанру, використовує комбінаторику його глобальних (загальноєвропейські) і національних (регіональні, східнослов'янські, 
зокрема українськs) традицій. Це відтворюється через діалог епох, риси якого проглядаються через жанровість. Жанрові витоки хорової вокальностіпісенність, речитативність, декламаційність - peaлізуються в поліфонізованій гомофонній фактурі. Наскрізною лінією розвитку фактури Концерту $\epsilon$ національна «партесна гомофонія», яка визначається опорою на вертикальну акордику, що постійно зберігається і лише зрідка переривається (наприклад, у фугато або в мікро-стретах).

Гармонічна хоральність створює стабільний пласт фактурного викладу, загальне тло, яке в підтексті означає колективний характер жанру музичної молитви, що реалізується в музиці Концерту на основі семантики сакральних текстів. Водночас акордова хоральність усередині фактурно-тематичних комплексів у М. Скорика тяжіє до мелосного принципу організації, що означає постійну присутність у ній мелодико-лінеарного компонента, який особливо активно діє всередині музичних строф і нівельований у «класичних» акордових кадансах. Так утворюється вже перший чотиритакт-рефрен, у якому до останніх двох акордів (домінантсептакорд і тоніка ля-мінору) діє принцип результативності вертикалей. Навіть перша 3 них дана 3 побічним тоном-затриманням - секундою «сі» у тенорів на тоніці ля-мінору.

Такий принцип будови вертикалі фактури зберігається від початку до кінця Концерту. Залежно від драматургічного розташування результативна акордика змінюється за регістровкою і кількістю голосів (від чотирьох до восьми) з підключенням гетерофонії стрічок, що йдуть від практики українського народного хорового співу, а також від кантової традиції. Гетерофонно-дублювальний принцип постійно наявний у фактурі Концерту, зокрема й у тому вигляді, який Т. Кравцов визначає як утворення «нейтральних зон», підкреслює типовість цього прийому для українського народного багатоголосся як основи фактурного мислення українських авторів, зокрема А. Штогаренка. У М. Скорика в зазначеному Концерті фактура, у зв'язку з їі хоровою специфікою, що йде від фольклору, як і в А. Штогаренка, складається так: «Досить часто вертикаль партитури диференціюється на два пласти, між якими виникає деякий висотний розрив («нейтральна зона»), подібно до того, як в українському народному багатоголосному співі між басом та іншими голосами (а в деяких випадках і між чоловічою й жіночою партіями) змішаного хору» (Кравцов, 1964: 14).

Варіанти фактури такого штучного багатоголосся, де дублювання $є$ головним фактуротворним прийомом, представлені в Концерті в різнома- нітних видах, а також у поєднанні 3 нормативним розташуванням вертикалі, яка в концертнохоровому письмі М. Скорика тяжіє до достатньої компактності. Найчастіше притаманне дотримання співвідношення тембрів голосів у межах кварти - теситурного унісону в хорі (діапазони хорових голосів диференціюються саме на цей інтервал). Це можна спостерігати навіть у генеральній кульмінації (т. 283), де шестиголосся, побудоване гетерофонно, усе ж компактно в межах кварто-тритонового співвідношення між чоловічими та жіночими партіями хору.

Мелодійна пісенна лінеарність у фактурі Концерту, що відображає специфіку хорового начала як субстанції концертно-хорового стилю, поєднується із соло. Антифони «хор - соло» становлять основу фактури як головного формотворного компонента в будові звучання Концерту. Водночас антифонний спів частіше представлений не дискретно, у чергуванні tutti- solo, а в поєднанні, накладанні, поліфонічності цих двох функцій концертування. Це показано відразу ж у вступі соло сопрано (т. 5), де ідея молитви як основи концепції музики Концерту реалізується в одноголоссі: уже 3 7-го такту партія соліста дублюється верхніми голосами жіночої та чоловічої груп хору.

Особливу фактурну і водночас образно-драматургічну роль у Концерті відіграє речитація, що $\epsilon$, разом із пісенним розспівом, важливим жанровим началом вокально-хорового інтонування. Уперше ремарка quasi recitativo 3'являється у 25-му такті, де починається персоніфікований діалог учасників хорового дійства (3 т. 28 вступає і соло тенора). Речитативи, що періодично виникають і далі, знаменують у формі Концерту зупинки-предикти до експонування й розвитку основних тем. Вони характерні не тільки для сольних партій, а й представлені в хорі, як, наприклад, у предиктовому проведенні рефрену «Господи, помилуй» (т. 183) перед Andante. Тут здійснюється антифонний речитативний діалог: соло сопрано акомпанує хор, який співає закритим ротом; у моменти паузування в сольній партії хор повторює текст речитації-молитви.

На речитації побудована й кода (від т. 318), де поєднані речитативи в сольних партіях і в партіях хору, а також антифонно зіставлені текстові символи даного Концерту-молитви - «Вічная пам'ять» і заключне «Амінь» у солістів та «Вічная пам'ять», «Алилуя», «Вічная пам'ять» у хору.

Діалогічність представлена в Концерті М. Скорика не тільки на фактурному, а й на ладо-гармонічному й тональному рівнях. Привертає увагу чітко позначений нарочито стилізованими 
автентичними класичними кадансами тональний план твору. Вихідний ля-мінор, відновлюваний у репризі та коді, у процесі розвитку всередині розділів форми барвисто перетворюється на основі як близьких, так і далеких тональних співвідношень. Композитор орієнтується на діатонічну тональність розширеного типу, близьку прокоф'євській (М. Скорик - автор монографії про ладову систему С. Прокоф'єва).

Для композитора тональності становлять не стільки логічні стрижні в організації форми Концерту (форма будується на основі смислів тексту, що відображається переважно через фактуротворення), скільки компоненти барвистої тембровозвукової (фонічної) картини в будові звучання музики твору. Головне тут - контрасти мажору та мінору, у зв'язку із чим використовуються різні форми синтезу цих ладів: паралельність (вона представлена в експозиції через паралельнозмінний лад ля-мінор - до-мажор), однойменність (повернення рефрену перед Andante (з. т. 50)), однотерцієвість (до-діез-мінор, фа-діезмінор, представлені в розвивальному епізоді експозиції від т. 28; у до-діез-мінорі - тональності, однотерцієвій до-мажору, дано й у фугато в рамках середнього розділу Andante). Тональний рух у Концерті завжди реагує на зміст текстів, наприклад, похмурий мі-бемоль мінор на словах «спасіння Моє!» миттєво змінюється світлим ре-мажором (тт. 121-125).

Ладовість у мовній стилістиці Концерту проявляється й на рівні будови ладо-інтонаційних комплексів усередині тих самих тональних зон. Тут діє принцип «ладового переливу» (М. Тіц), характерний для українського народного ладового інтонування. Цей принцип полягає в поєднанні на відстані мелодійних звуків ладу різного забарвлення, що постійно спостерігається в мелодиці Концерту М. Скорика. Найчастіше такі зміни відбуваються в сольних мелодійних речитаціях, наприклад, у ладовій модуляції з ре-мажора зі зниженими звуками шостого і другого ступенів до до-діезмажору, а в кадансі - до-діез-мінору (тт. 141-150).

Яскравого національного забарвлення ладомелодійному комплексу Концерту надають також інтонаційні формули, типові для української народнопісенної культури. Це - тетрахорд у зменшеній кварті, представлений в темі середнього розділу Andante (тт. 119-120, 168-169) у тенора та сопрано, які солюють. Наявність цієї інтонаційної формули в ладовому модусі Концерту не тільки підкреслює національний колорит музики, а й сприяє виявленню пафосної екстатики як типу інтонаційного змісту, що панує в даному творі.
Рухливості й динамічності в наскрізній формі одночастинного Концерту М. Скорика надають також ритмічні модуси, використання яких пов'язане із прозаїчною структурою текстів. Їхня дія характерна для середнього розділу - Andante, де чергуються розміри чотирьох, трьох, п'яти чвертей, причому п’ятидольний розмір затверджується як провідний на словах «сотвори мені» (со-тво-ри-ме-ні) (т. 217). Мінливість характерна і для ритмічного малюнка сольних і хорових партій, особливо в речитативних епізодах, де зміни ритмічної щільності у проголошенні тексту істотно динамізують виклад, надають йому необхідної для молитовності екстатики. Наприклад, в Andante наскрізного значення набуває група iз двох тріолей, на якій будується кульмінаційний вибух «Плачу, плачу і ридаю» 3 характерними ламентозними розспівами на перших двох звуках (тт. 284, 287).

При підході до цієї кульмінації показаний також драматургічний принцип subito, пов'язаний 3 ефектом раптовості й різкої зміни емоційних станів на всіх рівнях хорової композиції. Кульмінація не готується, а починається раптово після попереднього досить спокійного спаду - епізоду із солюючим сопрано на тлі витриманих акордів хору, що співає закритим ротом (Lento, тт. 269-282). В останній антифонній репліці хору, який повторює текст та інтонацію соло сопрано («забирає <..>») (тт. 281-282), встановлюється чітко виражений ефект динамічного згасанняспаду («і смерть все забирає»), безвиході, безсилля людини перед лицем лихої долі.

Кульмінація в тт. 283-288 буквально обвалюється своєю фактурною і динамічною масою (шестизвучна вертикаль, динаміка фортисимо), причому теситура різко злітає вгору, що особливо відчутно в партіях жіночих голосів. Така різка фактурно-реєстрова зміна в даному Концерті одинична і служить спеціальним засобом виділення кульмінації, що набуває напруженого динамічного ефекту не тільки завдяки раптовості, а і в загальній конструкції форми, відсунутої праворуч від зони золотого перетину (у тт. $234-244$ на цю зону припадає місцева кульмінація - poco agitato - фактурне крещендо у вигляді стретного вступу голосів від басів хору до соло сопрано, дроблення тексту на початкових словах строфи «Бо як би Ти <...>»). В інших випадках пропонована автором фактура у виконавському плані досить зручна, іiї ускладнення стосуються більшою мірою не виконавцівхористів, а роботи диригента-хормейстера, який координує їхні дії. 
Особливою та важливою для розуміння й утілення мовної стилістики Концерту $є$ авторська модель співвідношення музики та слова. М. Скорик використовує українські тексти відомих молитов, іде не від мовної інтонації, а від музики, за формулою «музика - узагальнює, слово - деталізує». У результаті жанрова форма Концерту набуває рис симфонічної фресковості, за якої хор (3 усім урахуванням його специфіки) і голоси солістів трактуються як інструменти загальної темброво-звукової маси, подібної до оркестрової («хорова інструментовка» (Гулеско, 1991: 12]). Пріоритет музики над словом, яким би парадоксальним це не здавалося, у духовному хоровому концерті дозволяє композитору, який мислить музично, домогтися цілісності й наскрізної лінії у драматургічному становленні форми, що набуває рис суцільної сюїтності з елементами сонатного антитетичного контрасту.

Це підтверджується й використанням тексту молитов із повторами та накладанням окремих слів, різними варіантами інтонування того часого слова або словосполучення, загальним імпровізаційним характером музичного викладу, що загалом характерно для поемного жанру, для моделі концерту-поеми, яка склалася в інструментальній музиці романтиків (Ф. Ліст). У свою чергу, варіаційність і варіантність $є$ ознаками такого атрибута концертно-хорового стилю, як тяжіння до свободи структури. Водночас вони $є$ способом подолання точних повторів, неминучих за контрастного сюїтного формотворення.

Без наявності наскрізних скріпних моментів форма одночастинного Концерту М. Скорика не набула б статусу інтонаційної єдності цілого. У сукупності 3 роллю фактури, тут проявляється логіка сонатності, яка ніби проступає крізь суцільну сюїтність як форма другого плану. Лише зовні форма Концерту контрастна і складена з декількох молитов. У ній $є$ наскрізна лінія розвитку, за якої схема форми, що складається із чотирьох розділів (буквено - А В C (R) A), виявляється зцементованою на основі: 1) пріоритету музичного модусу над текстовим, словесним; 2) принципу варіантно-варіаційного розвитку, який підсумовано в концертній поемності у вигляді «монотематичної (точніше, моноінтонаційної) контрастно-варіантної» форми (М. Тараканов); 3) наскрізної лінії, створюваної у фактурному розвитку, за якої в кожній новій фактурі виявляється зв'язок із попередньою й паростки наступної.

Концерт-молитва М. Скорика містить і жанр концерта-поеми, що визначається провідною роллю діалогічності, яка перетворюється у процесі музичного становлення на діалектичний контрастєдність. Композитор поєднує ці антитези, прагне досягти образно-концептуальної мети - створити музичну версію, переклад мовою музики богослужбової молитви в іiї колективному (хор) і особистісному (солісти) утіленні. Ідея діалогу проявляється в Концерті М. Скорика на всіх рівнях концертності, що визначає концептуальність як внутрішній, глибинний атрибут даного жанру взагалі, у його неорелігійному трактуванні й поготів.

Водночас світська образність, яка міцно пов'язана 3 національно-мовними джерелами, активізує сценічну репрезентативність. Це означає можливість навіть в академічному варіанті виконання показати внутрішню містеріальну театральність даного твору, вибудувати це виконання на основі діалогу-діалектики, розробити способи та прийоми втілення емоційної програми духовних і піднесених, але наділених людською вибуховою силою, напружених і внутрішньоконфліктних тем-образів твору.

Висновки. Духовний хоровий концерт є еталонною жанровою формою хорового концерту у вітчизняної традиції й основою для відродження цього жанру у практиці національного музикування. Жанрова форма «Духовного концерту» М. Скорика набуває рис симфонічної фресковості, за якої хор і голоси солістів трактуються як інструменти загальної темброво-звукової маси, подібної до оркестрової. Концерт створено в руслі нової релігійної хвилі. У ньому відображені основні типи жанрово-стильових моделей - духовнохорові твори минулого та їх персоніфікація в дусі національної ментальності. Збагачені стилемовні елементи твору вказують на принцип стилізації, майже цитування особливостей церковного співу, що йдуть від класики жанру українського хорового концерту (А. Ведель). Водночас значною мірою модифіковані такі елементи, як імітація церковного співу, респонсорність (хорові коментарі-рефрени після соло), загальний тип фактури, рясний контрастами. Головним у стилістичній модифікації моделі $\epsilon$ гармоніко-фактурний комплекс, рухи якого становлять основу формоутворення та драматургії твору. Поліфонізована гомофонна фактура хорової вокальності Концерту реалізується через пісенність, речитативність, декламаційність, а гармонічна фактура створює характер колективно-голосового інтонування жанру музичної молитви. У Концерті простежується широко розгорнений комплекс контрастних емоцій і стану, характерних для класичного хорового концерту. Композиторська індивідуальність проявляється від вибору текстів і їх компонування до компо- 
зиційної форми. М. Скорик веде діалог із традицією, упроваджує в хоровий концерт концертність інших видів мистецтв. Художнім контрапунктом до музичного змісту проходить сценічна репрезентативність, що може зводитися до просторового розміщення груп хору під час виконання.

\section{СПИСОК ВИКОРИСТАНИХ ДЖЕРЕЛ}

1. Александрова Н. Літургічна музика як жанрово-стильовий феномен у творчості вітчизняних композиторів кінця XX - початку XXI ст. : автореф. дис. ... канд. мистецтвознав.: 17.00.03. Одеса : ОНМА ім. А. В. Нежданової, 2008. $17 \mathrm{c}$.

2. Антоненко М. Православна духовна музика в системі української культури кінця XX - початку XXI ст. : автореф. дис. ... канд. мистецтвознав.: 26.00.01. Київ : НМАУ ім. П. І. Чайковського, 2020. 18 с.

3. Бєлік-Золотарьова Н. А. Оперно-хорова творчість українських композиторів другої половини XX ст. : шляхи розвитку: автореф. дис. ... канд. мистецтвознав.: 17.00.03. Харків : ХНУМ ім. І. П. Котляревського, 2011. 20 с.

4. Гулеско И. Хоровая литература. Новые жанрово-стилевые процессы в хоровой музыке 60-80-х гг. Харьков, $1991.83 \mathrm{c}$.

5. Кияновська Л. Мирослав Скорик : людина і митець : монографія. Львів : Видавець НКЖ «ї», 2008. 588 с.

6. Коменда О. Універсальна творча особистість в українській музичній культурі : автореф. дис. ... докт. мистецтвознав.: 17.00.03. Київ: НМАУ ім. П. І. Чайковського, 2020. 33 с.

7. Коновалова I. Феномен композитора в європейській музичній культурі XX ст. : особистісні та діяльнісні аспекти : автореф. дис. ... докт. мистецтвознав.: 17.00.03. Харків : ХНУМ ім. І. П. Котляревського, 2019. 39 с.

8. Кравцов Т. С. Полифония А. Я. Штогаренко: автореф. дис. ... канд. искусствовед. Киев, 1964. 16 с.

9. Куриляк І. Еволюція драматургічних функцій хору в українській опері: національно-естетичний вимір: дис. ... канд. мистецтвознав.: 17.00.03. Львів : ЛНМА ім. М. В. Лисенка, 2018. 195 с.

10. Мануляк О. Сакральна творчість львівських композиторів кінця XX - поч. XXI ст. у контексті провідних тенденцій сучасної релігійної музики : дис. ... канд. мистецтвознав.: 17.00.03. Львів : ЛНМА ім. М. В. Лисенка, 2009. 342 c.

11. Скорик М. Духовний концерт. Київ : Бібліотека камерного хору «Київ», 2005. С. 48-65.

12. Скорик М. Ладова система С. Прокоф’єва. Київ : Муз. Україна, 1969. 99 с.

13. Степурко В. Вияви мистецької інтроверсії у творчості композиторів України другої половини XX - початку XXI ст. : автореф. дис. ... канд. мистецтвознав.: 26.00.01. Київ : НАККіМ, 2017. 22 с.

14. Стець О. Хоровой концерт российских композиторов второй половины XX - начала XXI в. Метаморфозы жанра и его типология : автореф. дис. ... канд. искусствовед.: 17.00.02. Саратов, 2012. 30 с.

15. Тіц М. Про сучасні проблеми теорії музики. Київ, 1976. 158 с.

16. Харитонова Д. Різновиди символіки в українській інструментальній сонаті XX ст. : дис. ... канд. мистецтвознав.: 17.00.03. Київ : НМАУ ім. П. І. Чайковського, 2019. 296 с.

\section{REFERENCES}

1. Aleksandrova N. K. Liturgichna muzyka yak zhanrovo-stylyoviy fenomen $\mathrm{v}$ tvorchosti vitchyznyanyh kompozytoriv kinzya XX - pochatku XXI stolittya. [Liturgical music as the genre-styled phenomenon in domestic composers' creativity at the end of XX - beginning of XXI century]. Odesa: ONMA im. A. V. Nezhdanovoyi. Extended abstract of candidate's thesis: spec. 17.00.03 "Muzichne mystetstvo", 2008. 17 p. [in Ukrainian].

2. Antonenko M. M. Pravoslavna duhovna muzyka v systemi ukrayins'koyi kultury kinzya XX - pochatku XXI stolittya. [Orthodox sacred music in Ukrainian culture system at the end of XX - beginning of XXI century]. Kyiv: NMAU im. P. I. Chaikovs'kogo. Extended abstract of candidate's thesis: 26.00.01 "Theory and history of culture (art criticism)", 2020. 18 p. [in Ukrainian].

3. Belik-Zolotaryova N. A. Operno-horova tvorchist' ukrayins'kyh kompozytoriv drugoyi polovyny XX stolittya: shlyahy rozvytku. [Opera and Choral Art of Ukrainian composers in the second half of XX century: the ways of development]. Kharkiv: KhNUM im. I. P. Kotlyarevs'kogo. Extended abstract of candidate's thesis: 17.00 .03 "Muzichne mystetstvo", 2011. 20 p. [in Ukrainian].

4. Gulesko I. I. Horovaya literatura. Novyye zhanrovo-stilevyye protsessy v horovoy muzyke v 60-80 gg. [Choral literature. New genre-styled processes in choral music of 60-80 yy]. Kharkiv, Vydavets HDAK, 1991. 83 p. [in Russian].

5. Kyyanovska L. O. Myroslav Skoryk: lyudyna i mytets': monografiya. [Myroslav Skoryk: The Man and the Creator: monograph]. Lviv: Vydavets NKJ "Yi", 2008. 588 p. [in Ukrainian].

6. Komenda O. I. Universal'na tvorcha osobystist' v ukrayinskiy muzychniy kulturi. [Universal creative personality in Ukrainian music culture]. Kyiv: NMAU im. P. I. Chaikovs'kogo. Extended abstract of doctor's thesis: 17.00.03 "Muzichne mystetstvo", 2020. 33 p. [in Ukrainian].

7. Konovalova I. Y. Fenomen kompozytora v yevropeyskiy muzychniy kulturi: osobystisni ta diyal'nisni aspekty. [Composer phenomenon in European music culture of XX century: personal and activity aspects]. Kharkiv: KhNUM im. I. P. Kotlyarevs'kogo. Extended abstract of doctor's thesis: 17.00.03 "Muzichne mystetstvo", 2019. 39 p. [in Ukrainian].

8. Kravtsov T. S. Polifoniya A. Y. Shtogarenko. [Polyphony of A. Y. Shtogarenko]. Kyiv. Extended abstract of candidate's thesis, 1964. 16 p. [in Russian].

9. Kurylyak I. I. Evolyuziya dramaturgichnyh funktsiy horu v ukrayins'kiy operi: nazional'no-estetychny vymir. [Evolution of choral dramatic functions in Ukrainian opera: the national-esthetic survey]. Lviv: LNMA im. M. V. Lysenka. Extended abstract of candidate's thesis: 17.00.03 "Muzichne mystetstvo", 2018. 195 p. [in Ukrainian]. 
10. Manulyak O. M. Sakral'na tvorchist' l'vivs'kyh kompozytoriv kinzya XX - poch. XXI st. u konteksti providnyh tendentsiy suchasnoyi religiynoyi muzyky. [Sacred Art of Lviv composers at the end of XX - beginning of XXI century in the leading tendencies context of contemporary religious music]. Lviv: LNMA im. M. V. Lysenka. Extended abstract of candidate's thesis: 17.00.03 "Muzichne mystetstvo", 2009. 342 p. [in Ukrainian].

11. Skoryk M. "Duhovny kontsert”. [«Spiritual concert»]. Kyiv: Biblioteka Kamernogo khoru “Kyiv”, 2005. pp. 48-65 [in Ukrainian].

12. Skoryk M. S. Ladova systema S. Prokof'yeva. [S. Prokofyev's lad system]. Kyiv: Muz. Ukraina, 1969. 99 p. [in Ukrainian].

13. Stepurko V. Vyyavy mystets'koyi introversiyi u tvorchosti kompozytoriv Ukrayiny drugoyi polovyny XX - pochatku XXI stolittya. [Revelations of artistic introversion in Ukrainian composers' Art in the second part of XX - beginning of XXI century]. Kyiv: NAKKiM. Extended abstract of candidate's thesis: 26.00.01 "Theory and history of culture", 2017.22 p. [in Ukrainian].

14. Stets O. V. Horovoy kontsert rossiyskih kompozitorov vtoroy poloviny XX - nachala XXI veka. Metamorfozy zhanra i yego tipologiya. [Russian composers' choral concert of the second part of XX - beginning of XXI century. Genre metamorphoses and its typology]. Saratov. Extended abstract of candidate's thesis: 17.00.02 "Muzykalnoye iskusstvo". 2012. 30 p. [in Russian].

15. Tits M. D. Pro suchasni problemy teoriyi muzyki. [About contemporary problems in music theory]. Kyiv. 1976. 158 p. [in Ukrainian].

16. Haritonova D. V. Riznovydy simvoliki v ukrayinskiy instrumental'niy sonati XX stolittya. [Symbolics varieties in Ukrainian instrumental sonata of XX century]. Kyiv: NMAU im. P. I. Chaikovs'kogo. Extended abstract of candidate's thesis: 17.00.03 "Muzichne mystetstvo", 2019. 296 p. [in Ukrainian]. 